Komposisi kimia minyak atsiri buah sirih hijau... (M. Widyo Wartono, dkk.)

\title{
KOMPOSISI KIMIA MINYAK ATSIRI BUAH SIRIH HIJAU (PIPER BETLE L), KEMUKUS (PIPER CUBEBA L) DAN CABE JAWA (PIPER RETROFRACTUM VAHL)
}

\section{CHEMICAL CONTITUENT OF THE ESSENTIAL OILS FROM THE FRUITS OF PIPER BETLE L, PIPER CUBEBA L, AND PIPER RETROFRACTUM VAHL}

\author{
M. Widyo Wartono*, Ahmad Ainurofiq, Maya Ismaniar \\ Jurusan Kimia, FMIPA, Universitas Sebelas Maret \\ Jl. Ir. Sutami 36 A, Kentingan Surakarta 57126 Telp. (0271) 663375 \\ * email: m.widyo.wartono@gmail.com
}

\begin{abstract}
ABSTRAK
Tumbuhan genus Piper mempunyai kandungan minyak atsiri hampir disemua bagiannya, namun komposisi kimianya belum semua dilaporkan. Pada laporan ini kami melakukan isolasi dan identifikasi senyawa kimia minyak atsiri pada bagian buah tumbuhan Piper. Isolasi minyak atsiri buah Piper dilakukan dengan destilasi air menggunakan destilasi Stahl dan analisis komposisi kimia dengan kromatografi gasspektroskopi masa (GC-MS). Kandungan minyak atsiri buah sirih hijau (Piper betle) 1,4\% (v/b), cabe jawa (Piper retrofractum) 1\% (v/b), dan buah kemukus (Piper cubeba) 1,7\% (v/b). Hasil analisis GC-MS menunjukan kandungan utama minyak atsiri adalah senyawa golongan monoterpen, seskuiterpen dan fenil propanoid. Kandungan utama minyak atsiri buah sirih hijau ( $P$. betle) adalah eugenol $(12,36 \%)$, isokaryofillena $(9,55 \%)$ dan $\beta$-selinena $(8,09 \%)$, sedangkan komponen utama buah cabe jawa (Piper retrofractum) adalah isokaryofilen $(8,88 \%), \beta$-bisabolen $(7,01 \%)$ dan zingiberen $(6,32 \%)$, dan minyak atsiri buah kemukus (Piper cubeba) adalah spathulanol (27,05\%), sativen (8,73\%) dan germakren D $(7,50 \%)$.

Kata kunci : Piperaceae, Buah, Piper betle, Piper retrofractum, Piper cubeba.

ABSTRACT

The Piper genera contains essential oil in all part of the whole plant, but its chemical composition has not been completely reported. In this report we isolated and identified the chemical composition of essential oil from the fruits of Piper. The essential oil of Piper fruits were obtained by Stahl hydrodistilation and analyzed by GC-MS. The oil yielded $1.4 \%(\mathrm{v} / \mathrm{w})$ of Piper betle, $1 \%(\mathrm{v} / \mathrm{w})$ of Piper retrofractum, and $1.7 \%(\mathrm{v} / \mathrm{w})$ of Piper cubeba. The chemical compositions were analyzed by GC-MS showing the presences of monoterpenes, sesquiterpenes, and phenyl propanoids. The major components of $P$. betle were eugenol (12.36\%), isocaryophyllene $(9.55 \%)$ and $\beta$-selinene $(8.09 \%)$, whereas the Piper retrofractum were isocaryophyllene (8.88\%), $\beta$-bisabolene $(7.01 \%)$, and zingiberene $(6.32 \%)$, and the $P$. cubeba were spathulanol $(27.05 \%)$, sativen $(8.73 \%)$ and germacrene-D $(7.50 \%)$.
\end{abstract}

Keywords: Piperaceae, Fruits, Piper betle, Piper retrofractum, Piper cubeba. 


\section{PENDAHULUAN}

Indonesia memiliki kurang lebih 40.000 spesies tumbuhan tingkat tinggi. Diantara tumbuhan tersebut banyak yang dimanfaatkan sebagai obat maupun rempah-rempah. Salah satu tumbuhan obat adalah dari famili Piperaceae atau keluarga sirih-sirihan. Famili ini tersebar didaerah tropis dan subtropis, diantara genus-genus famili tumbuhan ini, genus Piper dengan sekitar 700 species dikenal sebagai tumbuhan rempah-rempah (Heyne, 1987). Tanaman genus Piper mengandung minyak atsiri yang banyak terkandung di seluruh bagian tubuhnya dan dimanfaatkan sebagai obat, rempahrempah dan bumbu dapur (Agusta. 2000). Bagian tumbuhan yang banyak dimanfaatkan umumnya adalah bagian daun dan buahnya. Tumbuhan genus Piper selain tumbuh di Indonesia juga banyak ditemukan tumbuh di negaranegara Asia Selatan, Tenggara dan Timur. Penelitian yang cukup intens mengenai kandungan kimia tumbuhan ini terutama dari India dan China. Kandungan kimia tumbuhan genus Piper cukup beragam misalnya untuk senyawa non volatil adalah alkaloid amida (Ahn et al., 1992; Banerji. et al., 2002; Park et al., 2007; Marques et al., 2007), lakton (Dharmaratne et al., 2002), flavonoid (Portet et al., 2007) dan lignan (Usia et al., 2005; Cabanillas et al., 2010). Kandungan kimia dari bagian volatil tumbuhan Piper diantaranya monoterpen, seskuiterpen dan fenilpropanoid (Agnes et al.,1986; Mundina et al., 1998; Martins et al., 1998; Dos Santos et al., 2001; Cysne et al., 2005; Elfahmi et al., 2006; Rali et al., 2007; Rahman et al., 2011). Penelitian tersebut juga menunjukkan manfaat senyawa kimia yang terkandung dalam genus Piper, antara lain sebagai anti mikroba (Khan and Siddiqui, 2007), sitotoksik (Tang et al., 2011), induksi apoptosis (Pan, et al., 2011), anti parasit (Flores et al., 2008), anti fungal
(Rahman et al., 2011) dan insektisida (Scott et al., 2008).

Di Pulau Jawa tumbuh beberapa spesies tumbuhan genus Piper seperti $P$. betle (Sirih Hijau), $P$. retrofractum (cabe Jawa), dan P. cubeba (Kemukus). Tumbuhan tersebut telah digunakan selama berabad-abad dalam bumbu masakan dan pengobatan tradisional, namun sedikit sekali informasi tentang kandunan kimia dari ketiga spesies diatas terutama yang diperoleh dari daerah Surakarta, Jawa Tengah. Beberapa penelitian yang telah dilakukan menggunakan sampel dari luar antara lain, minyak atsiri dari Piper betle (sirih hijau) dari Filipina mengandung kavibetol, kavibetol asetat, karyofilen, kamfen, eugenol, pinen, limonen dan safrol (Agnes et al., 1986). Komponen minyak atsiri buah Piper cubeba yang berasal dari Temanggung antara lain $\alpha$ pinen, sabinen, $\beta$-pinen, limonen, karyofilen, $\gamma$-kadinen dan kubebol (Elfahmi et al., 2006). Komponen utama minyak atsiri cabe jawa yang berasal dari Jawa Barat adalah karyofilen oksida, humulen dan bisabolen (Gabrielle, 2006). Pada paper ini kami mengisolasi minyak atsiri bagian buah dari tiga tumbuhan genus Piper yaitu $P$. betle L (sirih hijau), $P$. cubeba L (kemukus) dan $P$. retrofractum Vahl (cabe jawa) yang di kumpulkan dari daerah Surakarta dan menganalisa kandungan kimianya serta membandingkan profil komponen kimia penyusun minyak atsiri dengan referensi.

\section{METODE PENELITIAN}

\section{Alat dan Bahan}

Bahan yang digunakan adalah buah Piper retrofractum Vahl (cabe Jawa) yang diperoleh dari Pasar Gede Surakarta, buah Piper betle L (sirih hijau) dari Boyolali dan buah Piper cubeba L (kemukus) yang diperoleh dari 
Pasar Gede Surakarta dideterminasi di Fakultas Farmasi Universitas Gajah Mada.

\section{Prosedur Penelitian}

\section{Penyulingan minyak atsiri}

Sebanyak 50 gram masingmasing sampel didestilasi stahl dengan $250 \mathrm{~mL}$ akuades, selama kurang lebih 23 jam hingga volume minyak atsiri tidak bertambah lagi. Selanjutnya minyak atsiri dipisahkan. Minyak atsiri yang masih bercampur dengan sedikit air dipisahkan dengan menambahkan natrium sulfat anhidrat sampai jenuh.

\section{Analisis GC-MS}

Analisis komponen minyak atsiri menggunakan GC-MS SHIMADZU QP 2010S. Menggunakan kolom Rastek RXi-5MS (30 m/0,25mm), gas pembawa yang digunakan adalah Helium dengan tekanan $12 \mathrm{kPa}$, energy pengionan dengan Electron Impact $(70 \mathrm{eV})$, suhu injector $310{ }^{0} \mathrm{C}$ dan suhu kolom 60 $250^{\circ} \mathrm{C}$.

\section{HASIL DAN PEMBAHASAN}

\section{Kadar Minyak Atsiri}

Minyak atsiri yang diperoleh dari destilasi Stahl berupa cairan berwarna kuning jernih dan berbau khas tanaman dari jenis sirih-sirihan, dengan kadar minyak atsiri buah kemukus $1,7 \%$ (v/b), cabe jawa $1 \%$ (v/b), dan buah sirih hijau $1,4 \%$ (v/b). Kandungan minyak atsiri dalam suatu bahan tergantung dari umur tanaman dan kandungan mineral tempat hidupnya. Faktor fisika dan kimia juga dapat berpengaruh. Faktor fisika disebabkan oleh proses pengeringan dan penyimpanan. Lingkungan juga bisa mempengaruhi kadar dan kualitas minyak yang dihasilkan. Penyimpanan pada tempat yang terbuka menyebabkan sejumlah minyak akan menguap disertai pula oleh proses oksidasi. Faktor kimia disebabkan oleh komponen dalam minyak atsiri sebagian terdiri dari senyawa yang mengandung heteroatom oksigen seperti alkohol, aldehid, dan oksida, beberapa minyak atsiri bahkan mengandung senyawa-senyawa tersebut dalam jumlah besar. Adanya oksigen menyebabkan senyawa-senyawa tersebut mudah terurai.

\section{Identifikasi Minyak Atsiri}

\section{Komponen Minyak Atsiri Buah Kemukus (Piper cubeba)}

Hasil analisis dari spektrometer massa dapat diidentifikasi 28 senyawa (Tabel 1, sedangkan 3 senyawa tidak dapat didefinisikan karena memiliki pola fragmentasi yang sangat berbeda dengan referensi. Tiga senyawa tersebut bobot molekul yang sama dengan seskuiterpen sehingga bisa dikategorikan ke dalam senyawa seskuiterpen. Hasil analisis GCMS minyak atsiri buah kemukus menunjukan bahwa penyusun utama minyak atsiri buah kemukus adalah golongan monoterpen dan seskuiterpen. Dimana komponen terbanyak terutama adalah senyawa spatulenol, sativen, germakren-D dan linalol (seskuiterpen). Hal ini menunjukkan perbedaan sangat besar dengan referensi sebelumnya dimana buah Piper cubeba yang berasal dari Temanggung terutama mengandung senyawa $\alpha$-pinen, sabinen, $\beta$-pinen, limonen, karyofillen, $\gamma$-kadinen dan cubebol (Elfahmi et al., 2006). Perbedaan ini bisa disebabkan oleh banyak faktor antara lain umur buah, asal tempat, varietas tumbuhan atau proses yang lain. Hal ini menarik untuk diteliti perbandingan kandungan kimia dari buah kemukus dari daerah yang lain. 
Tabel 1. Komponen kimia buah kemukus (Piper cubeba)

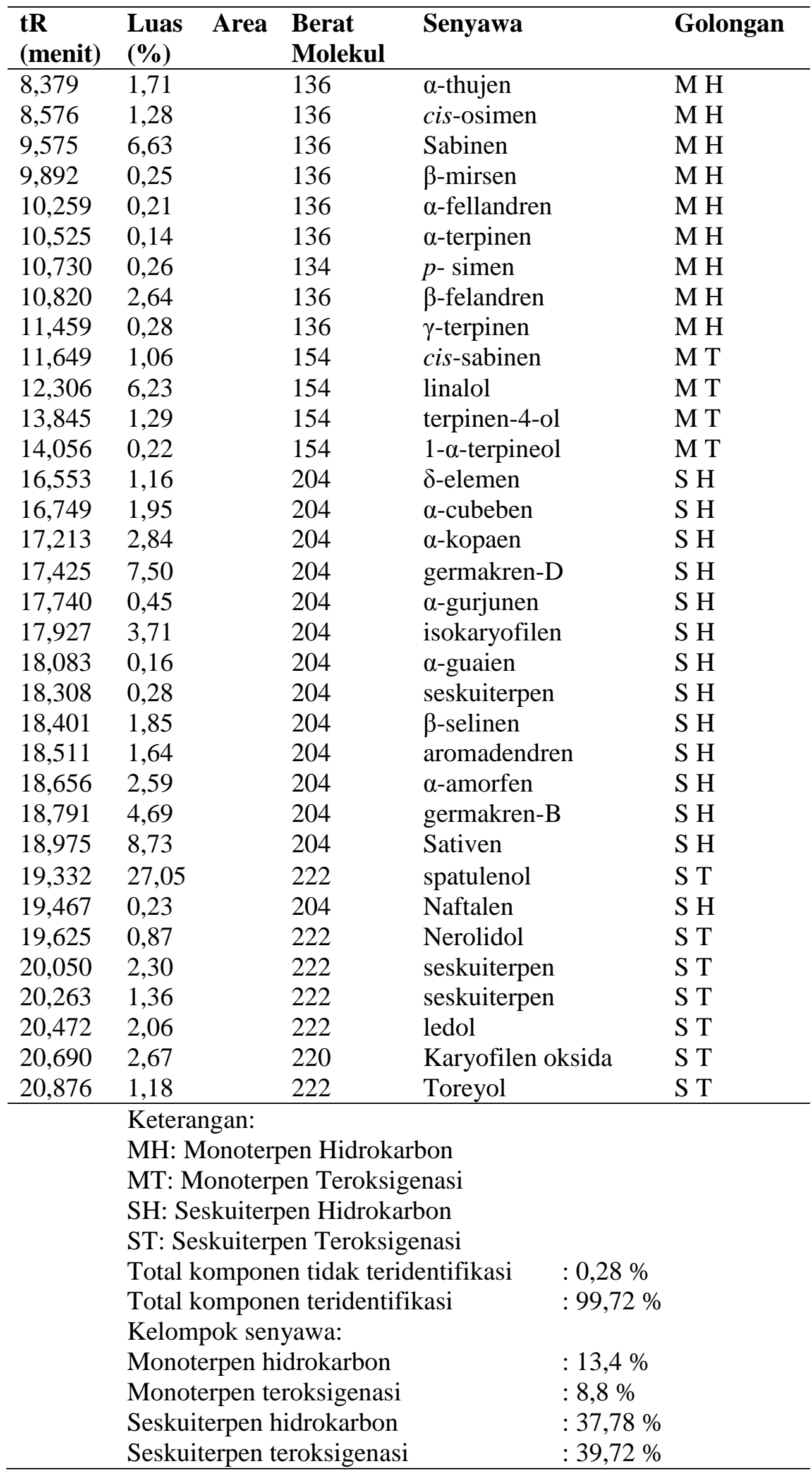


Komposisi kimia minyak atsiri buah sirih hijau... (M. Widyo Wartono, dkk.)

Komponen Minyak Atsiri Buah Cabe Jawa (Piper retrofractum)

Hasil analisis dari spektrometer massa dapat diidentifikasi 14 senyawa (Tabel 2.), sedangkan satu senyawa dikategorikan ke dalam golongan seskuiterpen. Hasil analisis juga menunjukkan hanya $48,1 \%$ senyawa yang teridentifikasi sedangkan $51,9 \%$ sisanya tidak teridentifikasi.

Tabel 2. Komponen kimia minyak atsiri buah cabe jawa (Piper retrofractum)

\begin{tabular}{|c|c|c|c|c|c|}
\hline $\begin{array}{l}\text { tR } \\
\text { (menit) }\end{array}$ & $\begin{array}{l}\text { Luas Area } \\
(\%)\end{array}$ & $\begin{array}{l}\text { Berat } \\
\text { Molekul }\end{array}$ & \multicolumn{2}{|c|}{ Saran Senyawa } & $\begin{array}{l}\text { Golong } \\
\text { an }\end{array}$ \\
\hline 12,238 & 0,53 & 136 & \multicolumn{2}{|c|}{$\alpha$-terpinolen } & M T \\
\hline 15,640 & 0,58 & 148 & \multicolumn{2}{|c|}{ metil-kavicol } & F P \\
\hline 16,543 & 0,30 & 204 & \multicolumn{2}{|l|}{$\delta$-elemen } & $\mathrm{S} \mathrm{H}$ \\
\hline 16,737 & 0,31 & 204 & \multicolumn{2}{|l|}{$\alpha$-kubeben } & $\mathrm{S} \mathrm{H}$ \\
\hline 16,953 & 0,55 & 164 & \multicolumn{2}{|l|}{ eugenol } & F P \\
\hline 17,194 & 0,75 & 204 & \multicolumn{2}{|l|}{$\alpha$-copaen } & $\mathrm{S} \mathrm{H}$ \\
\hline 17,391 & 2,04 & 204 & \multicolumn{2}{|l|}{$\beta$-elemen } & $\mathrm{SH}$ \\
\hline 17,517 & 0,12 & 204 & \multicolumn{2}{|c|}{$\alpha$-bergamonten } & $\mathrm{S} \mathrm{H}$ \\
\hline 17,723 & 0,56 & 204 & \multicolumn{2}{|c|}{ trans $-\alpha$ bergamonten } & S H \\
\hline 17,964 & 8,88 & 204 & \multicolumn{2}{|c|}{ isokaryofilen } & $\mathrm{S} \mathrm{H}$ \\
\hline 18,175 & 1,52 & 204 & \multicolumn{2}{|c|}{$\beta$-farnesen } & $\mathrm{S} \mathrm{H}$ \\
\hline 18,429 & 4,97 & 204 & \multicolumn{2}{|l|}{$\beta$-selinen } & $\mathrm{S} \mathrm{H}$ \\
\hline 18,837 & 6,32 & 204 & \multicolumn{2}{|l|}{ zingiberen } & $\mathrm{S} \mathrm{H}$ \\
\hline 18,923 & 4,02 & 204 & \multicolumn{2}{|l|}{$\delta$-guaien } & $\mathrm{S} \mathrm{H}$ \\
\hline 19,023 & 7,01 & 204 & \multicolumn{2}{|l|}{$\beta$-bisabolen } & $\mathrm{S} \mathrm{H}$ \\
\hline 19,237 & 2,02 & 204 & \multicolumn{2}{|c|}{$\beta$-seskuifelandren } & $\mathrm{S} \mathrm{H}$ \\
\hline 19,333 & 3,16 & 204 & \multicolumn{2}{|c|}{ seskuiterpen } & $\mathrm{S} \mathrm{H}$ \\
\hline 19,413 & 1,61 & 204 & \multicolumn{2}{|l|}{$\alpha$-humulen } & $\mathrm{S} \mathrm{H}$ \\
\hline 19,600 & 0,30 & 222 & \multicolumn{2}{|l|}{ nerolidol } & $\mathrm{S} \mathrm{T}$ \\
\hline 19,775 & 0,18 & 204 & \multicolumn{2}{|c|}{$\beta$-karyofilen } & $\mathrm{SH}$ \\
\hline 20,675 & 1,14 & 220 & \multicolumn{2}{|c|}{ isopathulenol } & $\mathrm{S} \mathrm{T}$ \\
\hline 20,825 & 1,23 & 220 & \multicolumn{2}{|c|}{ karyofilen oksida } & $\mathrm{S} \mathrm{T}$ \\
\hline & \multicolumn{5}{|l|}{ Keterangan: } \\
\hline & \multicolumn{5}{|c|}{ M H: Monoterpen Hidrokarbon } \\
\hline & \multicolumn{5}{|c|}{ M T: Monoterpen Teroksigenasi } \\
\hline & \multicolumn{5}{|c|}{ S H: Seskuiterpen Hidrokarbon } \\
\hline & \multicolumn{5}{|c|}{ S T: Seskuiterpen Teroksigenasi } \\
\hline & F P: Fenil Pr & panoid & & & \\
\hline & Total kompo & en tidak te & identifikasi & : $51,9 \%$ & \\
\hline & Total kompo & en terident & fikasi & $: 48,1 \%$ & \\
\hline & Kelompok se & yawa: & & & \\
\hline & Monoterpen & idrokarbor & & $: 0,53 \%$ & \\
\hline & Monoterpen & roksigena & & $:-$ & \\
\hline & Seskuiterpen & lidrokarbo & & $: 43,77 \%$ & \\
\hline & Seskuiterpen & eroksigena & & $: 2,67 \%$ & \\
\hline & Fenil Propan & & & $: 1,13 \%$ & \\
\hline
\end{tabular}


Hal ini bisa menunjukkan bahwa pada buah cabe jawa masih banyak senyawa yang belum dikenal sehingga tidak ditemukan dalam proses perbandingan dengan referensi. Hasil ini dapat juga dijadikan pedoman bahwa senyawa yang terkandung dalam cabe jawa perlu diidentifikasi lebih lanjut untuk mengetahui kandungan kimianya.

Hasil analisis GC-MS minyak atsiri buah cabe jawa yang berasal dari Pasar Gede Surakarta menunjukan bahwa komponen penyusun utama minyak atsiri buah cabe jawa adalah golongan monoterpen dan seskuiterpen, serta ada senyawa yang merupakan turunan dari fenil propanoid, yaitu metilkavicol dan eugenol. Komponen utama minyak atsiri buah cabe jawa adalah isokaryofilen dan bisabolen, senyawa ini memiliki kemiripan dengan penelitian sebelumnya bahwa komponen utama minyak atsiri cabe jawa yang berasal dari Jawa Barat adalah karyofilen oksida, humulen dan bisabolen (Gabrielle, 2006).

\section{Komponen Minyak Atsiri Buah Sirih Hijau}

Hasil analisis dari spektrometer massa dapat diidentifikasi 28 senyawa dan 4 senyawa dikategorikan ke dalam senyawa seskuiterpen. Komponen minyak atsiri buah sirih hijau yang berasal dari Boyolali menunjukan adalah golongan monoterpen dan seskuiterpen, serta ada beberapa senyawa yang merupakan turunan dari fenil propanoid, yaitu anetol, metil-kavikol dan eugenol. Komponen utamanya yaitu eugenol, $\beta$ dan isokaryofilen, selinen, kamfen dan aromadendren. Komponen utama ini bila dibandingkan tidak jauh berbeda dengan referensi sebelumnya dimana buah Piper betel dari Filipina mengandung senyawa kavibetol, kavibetol asetat, karyofilen, kamfen, eugenol, pinen, limonen dan safrol (Agnes et al.. 1986). Komponen teridentifikasi juga termasuk banyak yaitu $86,93 \%$.

Tabel 3. Komponen Senyawa Hasil Analisis Spektra Massa GC-MS Buah Sirih Hijau

\begin{tabular}{|c|c|c|c|c|}
\hline $\begin{array}{l}\text { tR } \\
\text { (menit) }\end{array}$ & $\begin{array}{l}\text { Luas Area } \\
(\%)\end{array}$ & $\begin{array}{l}\text { Berat } \\
\text { Molekul }\end{array}$ & Saran Senyawa & Golongan \\
\hline 8,363 & 0,70 & 136 & $\alpha$-felandren & $\mathrm{M} \mathrm{H}$ \\
\hline 8,577 & 2,68 & 136 & $\alpha$-pinen & M H \\
\hline 8,974 & 4,09 & 136 & kamfen & M H \\
\hline 9,532 & 1,40 & 136 & Sabinen & M H \\
\hline 9,632 & 0,33 & 136 & $\beta$-pinen & M H \\
\hline 9,879 & 0,31 & 136 & $\beta$-mirsen & M H \\
\hline 10,526 & 0,51 & 136 & $\alpha$-terpinen & M H \\
\hline 10,699 & 1,18 & 134 & $p$-simen & MH \\
\hline 10,873 & 2,10 & 154 & 1,8 -sineol & M T \\
\hline 11,448 & 0,80 & 136 & $\gamma$-terpinen & M H \\
\hline 12,073 & 0,21 & 136 & terpinolen & M H \\
\hline 12,252 & 1,36 & 136 & $\alpha$-terpinolen & M H \\
\hline 13,843 & 1,36 & 154 & Terpinene-4-ol & M T \\
\hline 14,142 & 0,19 & 148 & Anetol & F P \\
\hline 15,635 & 0,30 & 148 & metil kavikol & F P \\
\hline 15,865 & 0,45 & 196 & cis-sabinen & M T \\
\hline 16,532 & 0,26 & 204 & $\delta$-elemen & $\mathrm{S} \mathrm{H}$ \\
\hline 16,723 & 0,56 & 204 & $\alpha$-cubeben & $\mathrm{S} \mathrm{H}$ \\
\hline
\end{tabular}


Komposisi kimia minyak atsiri buah sirih hijau... (M. Widyo Wartono, dkk.)

Tabel 3. (Lanjutan)

\begin{tabular}{|c|c|c|c|c|}
\hline $\begin{array}{l}\text { tR } \\
\text { (menit) }\end{array}$ & $\begin{array}{l}\text { Luas Area } \\
(\%)\end{array}$ & $\begin{array}{l}\text { Berat } \\
\text { Molekul }\end{array}$ & Saran Senyawa & Golongan \\
\hline 17,102 & 12,36 & 164 & Eugenol & F P \\
\hline 17,204 & 1,76 & 204 & $\alpha$-kopaen & $\mathrm{S} \mathrm{H}$ \\
\hline 17,400 & 1,86 & 204 & allo-aromadendren & $\mathrm{S} \mathrm{H}$ \\
\hline 17,711 & 0,64 & 204 & $\alpha$-bergamoten & $\mathrm{S} \mathrm{H}$ \\
\hline 17,808 & 0,29 & 204 & Santalen & $\mathrm{S} \mathrm{H}$ \\
\hline 17,946 & 7,75 & 204 & B-karyofilen & $\mathrm{S} \mathrm{H}$ \\
\hline 18,164 & 0,71 & 204 & B-farnesen & $\mathrm{S} \mathrm{H}$ \\
\hline 18,426 & 6,14 & 204 & A-humulen & $\mathrm{S} \mathrm{H}$ \\
\hline 18,672 & 5,20 & 202 & seskuiterpen & $\mathrm{S} \mathrm{H}$ \\
\hline 18,822 & 3,74 & 204 & seskuiterpen & $\mathrm{S} \mathrm{H}$ \\
\hline 18,924 & 8,09 & 204 & B-selinen & $\mathrm{SH}$ \\
\hline 19,009 & 9,55 & 204 & iso-karyofilen & $\mathrm{S} \mathrm{H}$ \\
\hline 19,321 & 5,58 & 204 & aromadendren VI & $\mathrm{S} \mathrm{H}$ \\
\hline 20,190 & 1,66 & 220 & karyofilen oksida & $\mathrm{SH}$ \\
\hline 20,517 & 1,38 & 220 & seskuiterpen & $\mathrm{S} \mathrm{T}$ \\
\hline \multirow[t]{15}{*}{20,696} & 1,43 & 222 & seskuiterpen & $\mathrm{S} \mathrm{T}$ \\
\hline & \multicolumn{4}{|l|}{ Keterangan: } \\
\hline & \multicolumn{4}{|c|}{ MH: Monoterpen Hidrokarbon } \\
\hline & \multicolumn{4}{|c|}{ MT: Monoterpen Teroksigenasi } \\
\hline & \multicolumn{4}{|c|}{ SH: Seskuiterpen Hidrokarbon } \\
\hline & \multicolumn{4}{|c|}{ ST: Seskuiterpen Teroksigenasi } \\
\hline & \multicolumn{4}{|c|}{ FP: Fenil Propanoid } \\
\hline & \multicolumn{4}{|c|}{ Total komponen tidak teridentifikasi } \\
\hline & \multicolumn{4}{|c|}{ Total komponen teridentifikasi } \\
\hline & \multicolumn{4}{|c|}{ Kelompok senyawa } \\
\hline & \multicolumn{3}{|c|}{ Monoterpen hidrokarbon } & $: 16,3 \%$ \\
\hline & \multicolumn{3}{|c|}{ Monoterpen teroksigenasi } & $.391 \%$ \\
\hline & Seskuiterpen & hidrokarbo & $: 52$ & \\
\hline & Seskuiterpen & teroksigen & $: 4,4$ & \\
\hline & Fenil Propan & & $: 12$ & \\
\hline
\end{tabular}

\section{Perbandingan Minyak Atsiri}

Komposisi minyak atsiri dari ketiga spesies Piper secara keseluruhan menunjukan 54 senyawa penyusun minyak atsiri yang terdeteksi, dimana 19 senyawa termasuk golongan monoterpen, 32 senyawa termasuk golongan seskuiterpen, dan 3 senyawa termasuk senyawa turunan fenil propanoid. Piper cubeba memiliki 32 senyawa, diikuti Piper betle dengan 31 senyawa dan Piper retrofractum dengan
21 senyawa. Dalam setiap spesies Piper tersebut terdapat 6 senyawa yang sama yaitu, $\delta$-elemen, $\alpha$-copaen, iso-kariofilen, $\alpha$-cubeben, $\beta$-selinen dan kariofilen oksida. Hal ini dikarenakan ketiga sampel tersebut masih dalam satu genus sehingga dimungkinkan ada mempunyai persamaan dan perbedaan komponen kimia penyusun minyak atsiri.

Piper cubeba dan Piper retrofractum memiliki dua senyawa yang sama yaitu, $\alpha$-guaien dan nerolidol, dimana keduanya merupakan golongan 
seskuiterpen. Sedangkan Piper cubeba dan Piper betle memiliki 8 senyawa yang sama yaitu $\alpha$-felandren, sabinen, $\beta$ mirsen, $\alpha$-terpinen, $\quad \gamma$-terpinen, cissabinen, $p$-simen dan terpinen-4-ol, dimana kedelapan senyawa tersebut merupakan senyawa golongan monoterpen. Piper retrofractum dan Piper betle juga memiliki 8 senyawa yang sama yaitu, $\alpha$-terpinolen yang termasuk senyawa golongan monoterpen, metil-kavicol dan eugenol yang merupakan senyawa turunan fenil propanoid dan $\beta$-karyofilen, zingiberen, $\beta$-farnesen, $\alpha$-bergamonten, $\alpha$-humulen yang merupakan senyawa golongan seskuiterpen. Sehingga dapat disimpulkan Piper retrofractum Vahl dan Piper cubeba L memiliki hubungan kekerabatan yang dekat dengan Piper betle L hal ini disebabkan ketiga sampel diatas memiliki beberapa kesamaan senyawa, namun kekerabatan Piper cubeba dengan Piper retrofractum tidak terlalu dekat karena hanya memiliki dua kesamaan senyawa.

Ketiga spesies Piper tersebut secara keseluruhan memiliki 30 senyawa yang khas, yakni senyawa yang hanya muncul pada satu spesies. Piper cubeba memiliki 16 senyawa yang khas yaitu, $\alpha-$ tujen, cis-osimen, $\beta$-felandren, linalol, 1 $\alpha$-terpineol, germacren $\mathrm{D}, \alpha$-gurjunen, aromadendren, $\alpha$-amorfen, sativen, veridiflorol, naftalen, germakren B, sphatulenol, ledol dan toreyol. Piper retrofractum memiliki 5 senyawa yang khas yaitu, $\beta$-elemen, trans- $\alpha-$ bergamonten, $\quad \beta$-bisabolen, $\quad \beta$ seskuifelandren, isospathulenol. Sedangkan Piper betle memiliki 9 senyawa yang khas yaitu, $\alpha$-pinen, kamfen, $\beta$-pinen, 1-8 cineol, terpinolen, anetol, alloaromadendren, santalen dan aromadendren VI.

Senyawa yang khas pada setiap spesies sangat berguna sebagai penanda kimia untuk membedakan satu spesies dengan spesies lainnya dan mengetahui hubungan kedekatan kekerabatan antar spesies dalam satu genus. Disamping itu berguna untuk mengetahui kemurnian suatu minyak atsiri. Kadar komposisi dan jenis komponen dalam suatu minyak atsiri sangat bervariasi, hal ini bisa disebabkan oleh perbedaan spesies, metode isolasi, tempat tumbuh serta waktu pemanenan. Selain itu, komposisi minyak atsiri dapat berubah-ubah karena dapat mengalami penyusunan kembali secara intramolekuler.

Tabel 4. Perbandingan komposisi senyawa kimia penyusun minyak atsiri buah Piper cubeba, Piper retrofractum, dan Piper betle

\begin{tabular}{|c|c|c|c|}
\hline \multirow{2}{*}{ Senyawa } & \multicolumn{3}{|c|}{ Komposisi Monoterpen Minyak Atsiri Buah (\%) } \\
\hline & Piper cubeba & Piper retrofractum & Piper betle \\
\hline$\alpha$-tujen & 1,71 & - & - \\
\hline$\alpha$-felandren & 0,21 & - & 0,70 \\
\hline cis-osimen & 1,28 & - & - \\
\hline sabinen & 6,63 & - & 1,40 \\
\hline$\beta$-mirsen & 0,25 & - & 0,31 \\
\hline$\alpha$-terpinen & 0,14 & - & 0,51 \\
\hline$\beta$-felandren & 2,64 & - & - \\
\hline$\gamma$-terpinen & 0,28 & - & 0,80 \\
\hline cis-sabinen & 1,06 & - & 0,45 \\
\hline linalol & 6,23 & - & - \\
\hline terpinen-4-ol & 1,29 & - & 1,36 \\
\hline
\end{tabular}


Komposisi kimia minyak atsiri buah sirih hijau... (M. Widyo Wartono, dkk.)

Tabel 4. (Lanjutan)

\begin{tabular}{|c|c|c|c|}
\hline 1- $\alpha$-terpineol & 0,22 & - & - \\
\hline$\alpha$-terpinolen & - & 0,53 & 1,36 \\
\hline$\alpha$-pinen & - & - & 2,68 \\
\hline kamfen & - & - & 4,09 \\
\hline$\beta$-pinen & - & - & 0,33 \\
\hline 1,8-sineol & - & - & 2,10 \\
\hline terpinolen & - & - & 0,21 \\
\hline$p$-simen & 0,26 & - & 1,18 \\
\hline \multirow{2}{*}{ Komponen } & \multicolumn{3}{|c|}{ Komposisi seskuiterpen Minyak Atsiri Buah (\%) } \\
\hline & Piper cubeba & Piper retrofractum & Piper betle \\
\hline$\delta$-elemen & 1,16 & 0,3 & 0,26 \\
\hline$\alpha$-kopaen & 2,84 & 0,75 & 1,76 \\
\hline germakren-D & 7,50 & - & - \\
\hline$\alpha$-gurjunen & 0,45 & - & - \\
\hline iso-karyofilen & 3,71 & 8,88 & 9,55 \\
\hline$\alpha$-guaien & 0,16 & 4,02 & - \\
\hline$\alpha$-cubeben & 1,95 & 0,31 & 0,56 \\
\hline$\beta$-selinen & 1,85 & 4,97 & 8,09 \\
\hline aromadendren & 1,64 & - & - \\
\hline$\alpha$-amorfen & 2,59 & - & - \\
\hline germakren-B & 4,69 & - & - \\
\hline sativen & 8,73 & - & - \\
\hline veridiflorol & 2,23 & - & - \\
\hline naftalen & 0,23 & - & - \\
\hline nerolidol & 0,87 & 0,30 & - \\
\hline spatulenol & 27,05 & - & - \\
\hline ledol & 2,06 & - & - \\
\hline karyofilene oksida & 2,67 & 1,23 & 1,66 \\
\hline$\beta$-karyofilen & - & 0,18 & 7,75 \\
\hline toreyol & 1,18 & - & - \\
\hline$\beta$-elemen & - & 2,04 & - \\
\hline$\alpha$-bergamonten & - & 0,12 & 0,64 \\
\hline zingiberen & - & 6,32 & 3,74 \\
\hline trans- $\alpha$-bergamonten & - & 0,56 & - \\
\hline$\beta$-farnesen & - & 1,52 & 0,71 \\
\hline$\beta$-bisabolen & - & 7,01 & - \\
\hline$\beta$-seskuifelandren & - & 2,02 & - \\
\hline$\alpha$-humulen & - & 1,61 & 6,14 \\
\hline isospatulenol & - & 1,14 & - \\
\hline allo-aromadendren & - & - & 1,86 \\
\hline santalen & - & - & 0,29 \\
\hline aromadendren VI & - & - & 5,58 \\
\hline \multirow{2}{*}{ Komponen } & \multicolumn{3}{|c|}{ Komposisi Fenil propanoid Minyak Atsiri Buah (\%) } \\
\hline & Piper cubeba & Piper retrofractum & Piper betle \\
\hline metil-kavicol & - & 0,58 & 0,30 \\
\hline eugenol & - & 0,55 & 12,36 \\
\hline anetol & - & - & 0,19 \\
\hline
\end{tabular}




\section{KESIMPULAN}

Berdasarkan penelitian yang telah dilakukan diperoleh kesimpulan sebagai berikut:

1. Komposisi kimia penyusun minyak atsiri yang terdapat pada ketiga spesies Piper betle, Piper cubeba dan Piper retrofractum terdiri dari senyawa golongan monoterpen, seskuiterpen, dan fenil propanoid.

2. Minyak atsiri yang diperoleh berupa cairan berwarna kuning bening. Dengan kadar minyak atsiri tertinggi terdapat pada Piper cubeba sebesar $1,7 \%$ (v/b), diikuti Piper betle 1,4\% (v/b) dan Piper retrofractum $1 \%(\mathrm{v} / \mathrm{b})$. Piper cubeba dan Piper betle, serta Piper retrofractum dan Piper betle mempunyai hubungan kekerabatan yang lebih dekat dibandingkan Piper cubeba dan Piper retrofractum. Hubungan kekerabatan ketiga spesies Piper betle, Piper cubeba dan Piper retrofractum ditandai adanya senyawa $\delta$-elemen, $\alpha$ kopaen, isokaryofilen, $\alpha$ cubeben, $\beta$-selinen dan karyoflen oksida yang terkandung pada ketiga spesies tanaman dari genus Piper.

\section{DAFTAR PUSTAKA}

Agnes, M., Rimando, Byung H, H., Jeong, H, P., Magdalena C. 1986. Studies on the Constituen of Philippine Piper betle. Arch. Pha. Res 9(2). Hal: 93-97

Agusta, 2000. Minyak Atsiri Tumbuhan Tropika Indonesia. ITB, Bandung

Ahn, J.W., M.J. Ahn, O.P. Zee, E.J. Kim, S.G. Lee, H.J. Kim and I. Kubo, 1992, Piperidine
Alkaloids From Piper retrofractum Fruits, Phytochemistry, 31, pp. 36093612.

Banerji, A., M. Sarkar, R. Datta, P. Sengupta and K. Abraham, 2002, Amides From Piper brachystachyum and Piper retrofractum, Phytochemistry, 59, pp. 897-901.

Cabanillas, B.J., A.C. Le Lamer, D. Castillo, J. Arevalo, R. Rojas, G. Odonne, G. Bourdy, B. Moukarzel, M. Sauvain, and N. Fabre, 2010, Caffeic Acid Esters and Lignans from Piper sanguineispicum, J. Nat. Prod., 73, pp.1884-1890.

Cysne, J.B.,. K.M. Canuto, O.D. L. Pesso, .A.E.P. Nunes, and E.R. Silveira, 2005, Leaf Essential Oils Of Four Piper Species From The State Of Ceará Northeast Of Brazil, J. Braz. Chem. Soc., 16, pp. 1378-1381.

Dharmaratne, H.R.W., N.P.D.

Nanayakkara, I.A. Khan., 2002,

Kavalactones From Piper

Methysticum and Their ${ }^{13} \mathrm{C} \mathrm{Nmr}$ Spectroscopic Analyses, Phytochemistry, 59, pp. 429433

Dos Santos. P.R.D., D.de.L. Moreira, E.F. Guimaraes, and M.A.C. Kaplan, 2001, Essential Oil Analysis Of 10 Piperaceae Species From The Brazilian Atlantic Forest, Phytochemistry, 58, pp 547-551.

Elfahmi, B. Komar, R., Hermawa, J., Oliver, K., Quax, W. 2006. Essential Oil of Piper Cubeba: Essential Oil Constituents of Piper cubeba from Indonesia. Chapter V. Facilitair Bedrijf, University of Groningen, Netherland. Hal: 53-60 
Flores, N., I.A. Jimenez, A. Gimenez, G. Ruiz, D. Gutierrez, G. Bourdy, and I.L. Bazzocchi, 2008, Benzoic Acid Derivatives from Piper Species and Their Antiparasitic Activity, J. Nat. Prod. 1538 2008, 71, 15381543

Gabrielle, L. 2006. Studi Isolasi Dan Identifikasi Minyak Atsiri Cabe Jawa (Piper retrofractum Vahl). Skripsi. Universitas Indonesia, Jakarta

Heyne, K. 1987. Tumbuhan Berguna Indonesia (Terjemahan), Jilid 3, Badan Litbang Kehutanan, Jakarta.

Khan, M., and Siddiqui, M., 2007, Antimicrobial activity of Piper fruits, Natural Product Radiance, vol. 6(2), pp. 111113.

Marques, J.V., R.O. S. Kitamura, J. H.G. Lago, M.C.M. Young, E.F. Guimarães, and M.J. Kato, 2007, Antifungal Amides from Piper scutifolium and Piper hoffmanseggianum, J. Nat. Prod., 70, pp. 2036-2039.

Martins, A.P., L. Salgueiro, R. Vila, F. Tomi, S. Canigueral, J. Casanova, A.P. da Cunha and T. Adzet, 1998, Essential Oils From Four Piper Species, Phytochemistry, 49, pp. 20192023.

Mundina, M., R. Vila, F. Tomi, M.P. Gupta, T. Adzet, J. Casanova, and S. Canigueral, 1998, Leaf Essential Oils Of Three Panamanian Piper Species Phytochemistry, 47, pp. 12771283.

Pan, L., S. Matthew, D.D. Lantvit, X. Zhang, T. N Ninh, H Chai, E.J. C. de Blanco, D.D. Soejarto,
S.M. Swanson, and A.D.

Kinghorn, 2011, Bioassay-

Guided Isolation of

Constituents of Piper sarmentosum Using a

Mitochondrial Transmembrane Potential Assay, J. Nat. Prod. 74, pp. 2193-2199

Park, B.S., D.J. Son, Y. H. Park, T.W. Kim, and S.E. Lee, 2007, Antiplatelet effects of acidamides isolated from the fruits of Piper longum $\mathrm{L}$. Phytomedicine, 14, pp. 853855.

Portet B,. N. Fabre, V. Roumy, H. Gornitzka, G. Bourdy, S. Chevalley, M. Sauvain, A. Valentin, C. Moulis, 2007, Activity-Guided Isolation Of Antiplasmodial Dihydrochalcones and Flavanones From Piper hostmannianum Var. berbicense, Phytochemistry, 68, pp 1312-1320.

Rahman, A., S.M. Al-Reza, and S.C. Kang, 2011, Antifungal Activity of Essential Oil and Extracts of Piper chaba Hunter Against Phytopathogenic Fungi, J. Am. Oil Chem Soc, 88, pp. 573-579.

Rali T., S.W. Wossa, D.N. Leach, and P.G. Waterman, 2007, Volatile Chemical Constituents of Piper aduncum $\mathrm{L}$ and Piper gibbilimbum C. DC (Piperaceae) from Papua New Guinea, Molecules, 12, pp. 389394.

Scott, I.M., H.R. Jensen, BJ..R. Philogene, J. T. Arnason, 2008, A review of Piper spp. (Piperaceae) phytochemistry, insecticidal activity and mode 
of action, Phytochem Review, 7, pp. 65-75.

Tang, G.H. D.M. Chen, B.Y. Qiu, L. Sheng, Y.H. Wang, G.W. Hu, F.W. Zhao, L.J. Ma, H.Wang, Q.Q. Huang, J.J. Xu, C.L. Long, and J. Li, 2011, Cytotoxic Amide Alkaloids from Piper boehmeriaefolium, J. Nat. Prod., 74, pp. 45-49

Usia, T., T. Watabe, S. Kadota, and Y. Tezuka, 2005, Potent Cyp3a4 Inhibitory Constituents Of Piper cubeba, J. Nat. Prod, 68, pp. 64-68. 